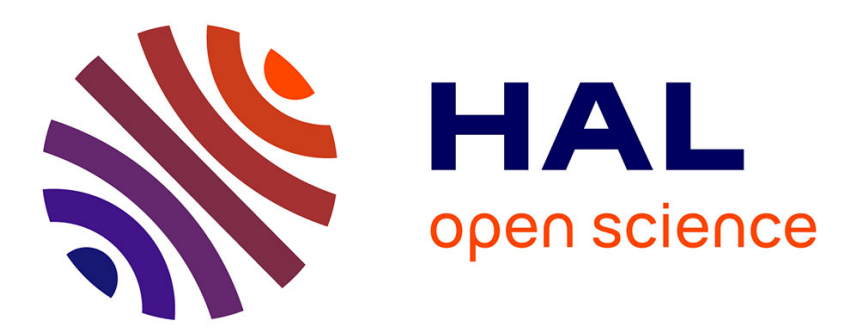

\title{
High temperature thermal diffusivity of nickel-based superalloys and intermetallic compounds
}

\author{
A. Hazotte, B. Perrot, P. Archambault
}

\section{To cite this version:}

A. Hazotte, B. Perrot, P. Archambault. High temperature thermal diffusivity of nickel-based superalloys and intermetallic compounds. Journal de Physique IV Proceedings, 1993, 03 (C7), pp.C7-351C7-354. 10.1051/jp4:1993754 . jpa-00252172

\section{HAL Id: jpa-00252172 https://hal.science/jpa-00252172}

Submitted on 1 Jan 1993

HAL is a multi-disciplinary open access archive for the deposit and dissemination of scientific research documents, whether they are published or not. The documents may come from teaching and research institutions in France or abroad, or from public or private research centers.
L'archive ouverte pluridisciplinaire HAL, est destinée au dépôt et à la diffusion de documents scientifiques de niveau recherche, publiés ou non, émanant des établissements d'enseignement et de recherche français ou étrangers, des laboratoires publics ou privés. 


\title{
High temperature thermal diffusivity of nickel-based superalloys and intermetallic compounds
}

\author{
A. HAZOTTE, B. PERROT and P. ARCHAMBAULT
}

Laboratoire de Science et Génie des Matériaux Métalliques, URA 159 du CNRS, Ecole des Mines, Parc de Saurupt, 54042 Nancy cedex, Fance

\begin{abstract}
By means of an installation developed in our laboratory, we measured the thermal diffusivity $(\alpha)$ as a function of temperature for several single and polycrystal nickel-based superalloys as well as for different intermetallic compounds with a $\mathrm{L}_{2}$ ( $\mathrm{Ni3Al}$, Ni3Si, Ni3Ge, Ni3Fe, Zr3Al, Co3Ti), L10 (TiAl) or $\mathrm{B} 2$ ( $\mathrm{NiAl}$ ) structure. In the case of nickel-based superalloys, the experiments pointed out an unexpected but reproductible slope change in the $\alpha=\mathrm{f}(\mathrm{T})$ curves at about $750^{\circ} \mathrm{C}$, which is not explained at this time. It was shown that the initial microstructure, the crystal orientation and the grain size seem to have no noticeable influence on the thermal behaviour. Slight variations between different alloys were rather attributed to a chemical composition effect. In the case of intermetallic compounds the temperature dependence of the thermal diffusivity appeared to drastically change from an alloy to an other. Thus, no clear relation could be found between thermal behaviour, crystallographic structure and strength temperature dependence of these alloys.
\end{abstract}

\section{INTRODUCTION}

The thermal diffusivity of a material is defined as $\alpha=\lambda / \rho c$ where $\lambda, \rho$ and $c$ are the thermal conductivity, density and specific heat, respectively. From a thermal point of view, it characterizes the ability of the material to diffuse a thermal perturbation. From the material side and due to this definition, the measurement of this property can reveal processes related to chemical composition as well as structural transformations.

The most commonly used technique for measuring thermal diffusivity is called "flash method". It consists in applying a pulse of energy on the front face of a plate sample and in following the resulting thermal evolution of its rear face. Using an apparatus based on this principle, we recently performed experiments on single crystals of nickel-based superalloys and of a Ni3Al intermetallic compound [1]. They revealed an unexpected thermal behaviour since the $\alpha=f(T)$ curves of superalloys and $\mathrm{Ni}_{3} \mathrm{Al}$ presented a sudden slope change and a maximum, respectively, at about $750^{\circ} \mathrm{C}$. This phenomenon was not explained although the analogy with mechanical behaviour (end of a plateau or maximum of yield stress at the same temperature) was noted. In the meantime, new experiments have been performed on different single and polycrystal superalloys with high volume fractions of $\gamma$ phase as well as on several intermetallic alloys. The aim of this study was to confirme our first results and to determine if the thermal-mechanical analogy was fortuitous or not. This paper reports and discusses the results of this investigation.

\section{EXPERIMENTAL PROCEDURE}

The chemical compositions of the six nickel-based superalloys concerned with the present work are given in Table 1, together with their initial heat treatments and their grain structure. The value of high temperature $\gamma-\gamma$ misfit is also indicated when available. As described in [1], TT1 and TT2 heat treatments applied to CMSX2 alloy resulted in coherent and "degenerated" precipitates, respectively. In the case of 01 
polycrystal alloy, TT1 and TT2 treaments led to different grain sizes, as indicated in Table 1. Different intermetallic compounds, the chemical compositions of which are reported in Table 2, were also studied. The structure of the corresponding ordered phase as well as the temperature of the peak of maximum strength if any are also given. The polycrystalline alloys were elaborated using induction melting in a cold $\mathrm{Cu}$ crucible then submitted to homogenization heat treatments indicated in Table 2 . As far as possible, these heat treatments were chosen similar to those used by Wee et al in their studies dealing with the temperature dependence of strength of $\mathrm{L}_{2} 2$ intermetallics $[2,3]$.

Cylindrical samples $(\varnothing 10 \mathrm{~mm}$, thickness $2 \mathrm{~mm}$ ) were prepared by spark erosion and/or diamond saw cutting. Their main faces were polished to ensure a good parallelism, then sand-blasted. The installation used for the diffusivity measurements has been described elsewhere [4]. The pulse of energy is obtained with a laser YAG. The pulse duration is about $500 \mathrm{~ms}$ and the energy level ranges between 5 and $30 \mathrm{~J}$. The thermal signal is detected with a $\mathrm{HgCdTe}$ detector cooled to liquid $\mathrm{N} 2$ temperature. The sample is located in a furnace under neutral atmosphere. The measurement can be performed between room temperature up to $1500^{\circ} \mathrm{C}$ with a minimum temperature step of $20^{\circ} \mathrm{C}$ and with a precision better than $5 \%$. The installation is completely controled with a Macintosh II computer from APPLE. The software (developped in the LSG2M) is in charge of all the operations and allows automatic measurements on heating, cooling $\left(5^{\circ} \mathrm{C} / \mathrm{mn}\right)$ and versus time at any given temperature. As an example, a complete $\alpha=f(T)$ curve between 20 and $1400^{\circ} \mathrm{C}$ is obtained in 8 hours without any manipulation.

\begin{tabular}{|c|c|c|c|c|c|c|c|c|c|c|c|}
\hline & $\mathrm{Ni}$ & $\mathrm{Al}$ & Co & $\mathrm{Cr}$ & $\mathrm{Ta}$ & W & Mo & $\mathrm{Ti}$ & $\begin{array}{c}\delta \\
(\%)\end{array}$ & $\begin{array}{c}\text { grain } \\
\text { orientat. }\end{array}$ & Heat Treatments \\
\hline$\overline{\text { AM1 }}$ & base & 5.1 & 6.5 & $\overline{7.4}$ & 8.0 & 5.3 & 2.0 & 1.2 & -0.25 & \begin{tabular}{|c|}
$<001>$ \\
$<111>$ \\
D.S. $<001>$ \\
polycrystal
\end{tabular} & $1300^{\circ} \mathrm{C} / 3 \mathrm{~h}$. - air cooled \\
\hline AM3 & base & 5.86 & 5.61 & 8.04 & 3.43 & 4.91 & 2.2 & 2.0 & - & $<001>$ & $1310^{\circ} \mathrm{C} / 3$ h. - a. c. \\
\hline MC2 & base & 4.87 & 5.08 & 7.86 & 6.05 & 7.85 & 2.07 & 1.53 & -0.4 & $<001>$ & $1300^{\circ} \mathrm{C} / 3$ h. - a.c. \\
\hline 01 alloy & base & 5.0 & - & 6.0 & 7.0 & - & 2.0 & - & +0.37 & polycrystal & 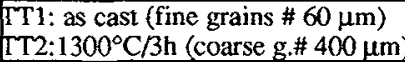 \\
\hline$\overline{\text { CMSX2 }}$ & base & 5.6 & 4.6 & 8.0 & 6.0 & 8.0 & 0.6 & 1.0 & -0.18 & $<001>$ & $\begin{array}{l}\text { TT1: } 1315^{\circ} \mathrm{C} / 3 \mathrm{~h} .- \text { a.c. } \\
\text { TT2: TT1 + cooling at }-0.01^{\circ} \mathrm{C} / \mathrm{min}\end{array}$ \\
\hline CMSX2 & base & 5.3 & 5.2 & 7.4 & 7.7 & 7.3 & 0.5 & 0.2 & -0.09 & $<001\rangle$ & $1315^{\circ} \mathrm{C} / 3 \mathrm{~h}$. - a.c. \\
\hline
\end{tabular}

TABLE 1 : Chemical compositions (wt\%), high temperature $\gamma-\gamma$ lattice mismatch $\delta$ (measured at $1050{ }^{\circ} \mathrm{C}$ or $1100^{\circ} \mathrm{C}$; ref. $\left.[5,6]\right)$, crystal orientations and initial heat treatments of the six superalloys studied in the present work

\begin{tabular}{|c|c|c|c|c|}
\hline Alloy & Composition & Heat Treatment & $\begin{array}{l}\text { ordered } \\
\text { struct. }\end{array}$ & $\begin{array}{c}\text { strength } \\
\text { peak }\end{array}$ \\
\hline $\mathrm{Zr} 3 \mathrm{Al}$ & 25 at.\% $\mathrm{Al}$ & $1300^{\circ} \mathrm{C} / 1 \mathrm{~h}+600^{\circ} \mathrm{C} / 15 \mathrm{~d}$ furnace cooled & $\mathrm{L} 12$ & $\# 500^{\circ} \mathrm{C}$ \\
\hline $\mathrm{NiAl}$ & 50 at. $\% \mathrm{Al}$ & $1000^{\circ} \mathrm{C} / 4 \mathrm{~d}-$ f.c. & $\overline{B 2}$ & no \\
\hline Ni3Ge & 25 at. $\% \mathrm{Ge}$ & $1000^{\circ} \mathrm{C} / 5 \mathrm{~d}-\mathrm{f} . \mathrm{c}$. & $\mathrm{L} 12$ & $\# 450^{\circ} \mathrm{C}$ \\
\hline $\mathrm{Ni}-\mathrm{Ge}$ & 23.5 at.\% $\mathrm{Ge}$ & $1000^{\circ} \mathrm{C} / 5 \mathrm{~d}$-f.c. & $\mathrm{L} 12$ & - \\
\hline $\mathrm{NizFe}$ & 25 at. $\% \mathrm{Fe}$ & $500^{\circ} \mathrm{C} / 12 \mathrm{~d}$ - f. c. & $\mathrm{L}_{2}$ & no \\
\hline $\mathrm{Co} 3 \mathrm{Ti}$ & 25 at.\% Ti & $1050^{\circ} \mathrm{C} / 10 \mathrm{~d}+1000^{\circ} \mathrm{C} / 2 \mathrm{~d}-$ f.c. & $\mathrm{LI}_{2}$ & $\# 750^{\circ} \mathrm{C}$ \\
\hline TiAl & 48.8 at. $\% \mathrm{Al}+2.2$ at. $\% \mathrm{~V}$ & $\begin{array}{l}\text { TT1 : } 1400^{\circ} \mathrm{C} / 0.5 \mathrm{~h}-\text { f. c. } \\
\text { TT2: } 1250^{\circ} \mathrm{C} / 1 \mathrm{~h}-\text { f.c. }\end{array}$ & $\mathrm{L} 10$ & $\# 600^{\circ} \mathrm{C}$ \\
\hline Ni3Al single $\bar{X}$ & 22.5 at.\% $\mathrm{Al}+0.25$ at. $\% \mathrm{Hf}$ & $1200^{\circ} \mathrm{C} / 1 \mathrm{~d}$ & $\mathrm{L1}_{2}$ & $\# 650^{\circ} \mathrm{C}$ \\
\hline $\mathrm{Ni3Al}$ & 25 at.\% $\mathrm{Al}$ & $1200^{\circ} \mathrm{C} / 4 \mathrm{~d}$ - f. c. & $\mathrm{L}_{2}$ & - \\
\hline $\mathrm{Ni} 3 \mathrm{Si}$ & 25 at.\% Si & $1050^{\circ} \mathrm{C} / 1 \mathrm{~d}+900^{\circ} \mathrm{C} / 2 \mathrm{~d}+800^{\circ} \mathrm{C} / 4 \mathrm{~d}-$ f. c. & $\mathrm{L} 12$ & $\# 400^{\circ} \mathrm{C}$ \\
\hline
\end{tabular}

TABLE 2 : Chemical compositions and homogenization heat treatments of the intermetallic compounds studied in the present work. All samples were polycrystals except one Ni3Al single crystal. The crystallographic structure of the corresponding ordered phase is also indicated together with the strength peak temperature in the case of a positive temperature dependence. 


\section{RESULTS AND CONCLUSIONS}

Figure 1 shows the evolution of thermal diffusivity from room temperature up to $1300^{\circ} \mathrm{C}$ for the six nickel based superalloys with different orientations and different heat treaments. Table 3 gives the values of diffusivity measured at room temperature in the case of AM1 and 01 alloys with different grain structures (at least 20 measurements per sample). This set of experiments leads to the following conclusions :

- all the $\alpha=f(T)$ curves are very similar, confirming the existence of a clear change in the thermal behaviour of these alloys between $700^{\circ} \mathrm{C}$ and $800^{\circ} \mathrm{C}$.

- heat treatments (i.e. microstructure and/or internal stress state), crystal orientation and grain size do not seem to explicitely influence the thermal diffusivity, at least in the limit of our experimental conditions. In the same way, no direct relation can neither be found between diffusivity and misfit magnitude.

- small variations can still be observed between the diffusivity levels of the different alloys. At the light of the preceding remarks, this is supposed to be mainly related to chemical composition variations.

- at higher temperatures, the slope of $\alpha=\mathrm{f}(\mathrm{T})$ curve varies from an alloy to another (this is especially noticeable in the case of 01 alloy). The reason for this is not clear and works have to be done to precise the parameters responsible for these differences ( precipitate volume fraction, dissolution kinetics, chemical composition ...).

Figure 2 shows the $\alpha=f(T)$ curves obtained for the intermetallic compounds of Table 2 . The thermal evolution appears to drastically change from an alloy to an other. It is verified that thermal diffusivity is influenced by sligh variations of chemical composition (see for instance the case of Ni$\mathrm{Ge}$

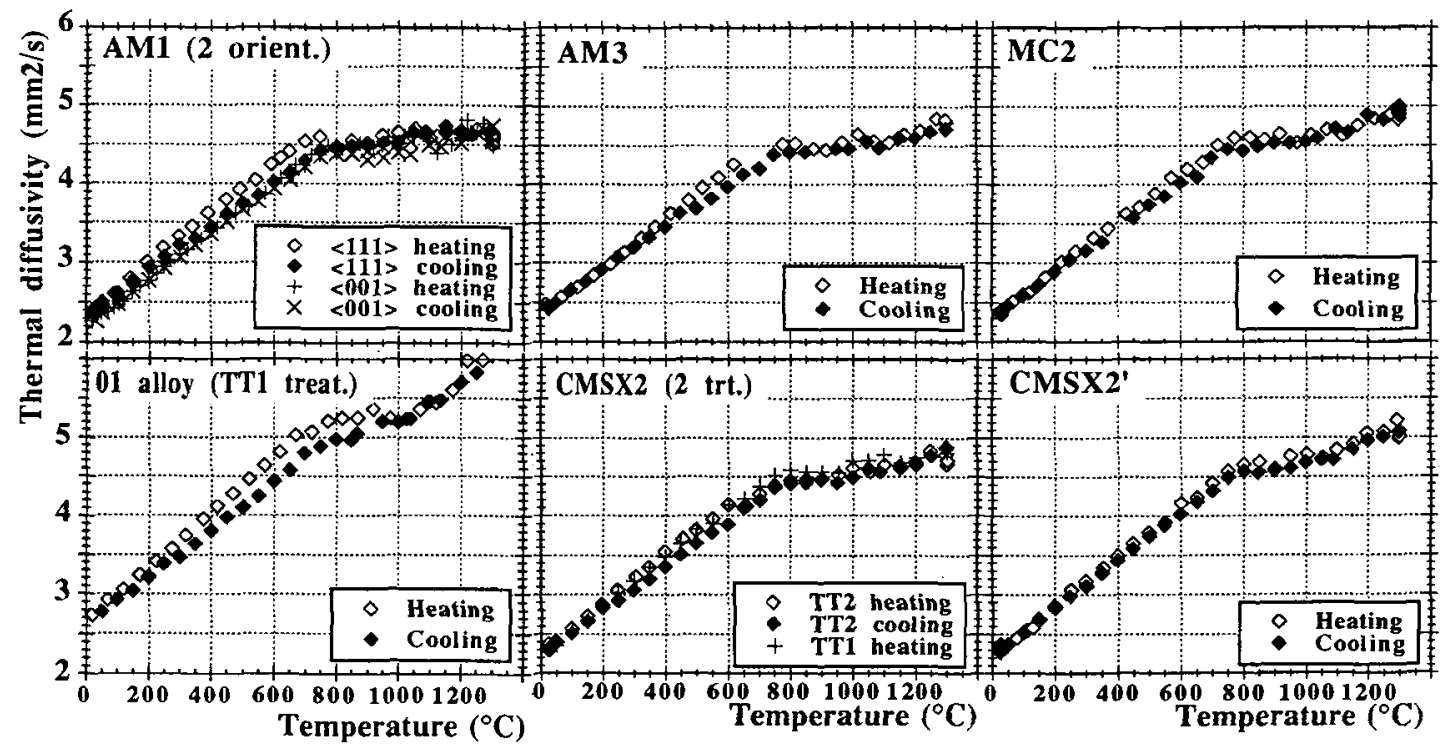

FIGURE 1 : Temperature dependence of thermal diffusivity for the six superalloys of Table 1

\begin{tabular}{|c|c|c|c|}
\hline AM1 alloy & single crystal & direct. solidified & polycrystal \\
\hline
\end{tabular}

\begin{tabular}{|c|c|c|}
\hline 01 alloy & fine grains (TT1 treatment) & coarse grains (TT2 treat.) \\
\cline { 2 - 3 } & $2.81 \pm 0.015$ & $2.79 \pm 0.01$ \\
\hline
\end{tabular}

TABLE 3 : Thermal diffusivity $\left(\mathrm{mm}^{2} / \mathrm{s}\right)$ measured at room temperature in the case of AM1 and 01 alloys with different grain structures (at least 20 measurements per sample) 
alloys) and that it is very sensitive to magnetic transformation $\left(\mathrm{Ni}_{3} \mathrm{Fe}\right)$ and probably also to order-disorder transformation (stoechiometric $\mathrm{Ni}_{3} \mathrm{Al}$ ard $\mathrm{Ni}_{3} \mathrm{Ge}$ alloys). However, although some curves seem to present a singularity in the vicinity of the strength peak temperature $\left(\mathrm{Ni}_{3} \mathrm{Al}, \mathrm{TiAl}, \mathrm{Ni}_{3} \mathrm{Ge}\right)$, this set of experiments showed that this situation is not general. Moreover, no direct relation can even be found between the crystallographic structure and the general trend of the diffusivity temperature dependence. At this time no theoretical approach is still capable to forecast the thermal properties of this type of alloys. Thus, a more precise and systematic experimental characterization of their thermal behaviour appears to be necessary.

\section{ACKNOWLEDGEMENTS}

Nickel-based single crystal superalloys were available through the french research programmes G.S. "MicroStructure et Propriétés des Superalliages Monocristallins" and C.P.R. "Stabilité Structurale des Superalliages Monocristallins". The other alloys were elaborated at L.S.G.2M by J.P. Houin or kindly provided by A. Fredholm (01 alloy), R. Tintillier (D.S. and polycrystal AM1), G. Molénat and P. Caron (single crystal Ni3Al) and T. Grosdidier (TiAl).

\section{REFERENCES}

[1] ARCHAMBAULT P. and HAZOTTE A., Scripta metall. et mater. 28 (1993) 423.

[2] WEE D.M.and SUZUKI T., Trans. JIM 20 (1979) 634

[3] WEE D.M., NOGUCHI O., OYA Y. and SUZUKI T., Trans. JIM 21 (1980) 237

[4] ARCHAMBAULT P. and SCHREIBER D. LSG2M Internal Report (1991)

[5] FREDHOLM A., PhD Thesis - Ecole des Mines de Paris FRANCE (1987)

[6] GROSDIDIER T., PhD Thesis - Institut National Polytechnique de Lorraine Nancy FRANCE (1992)

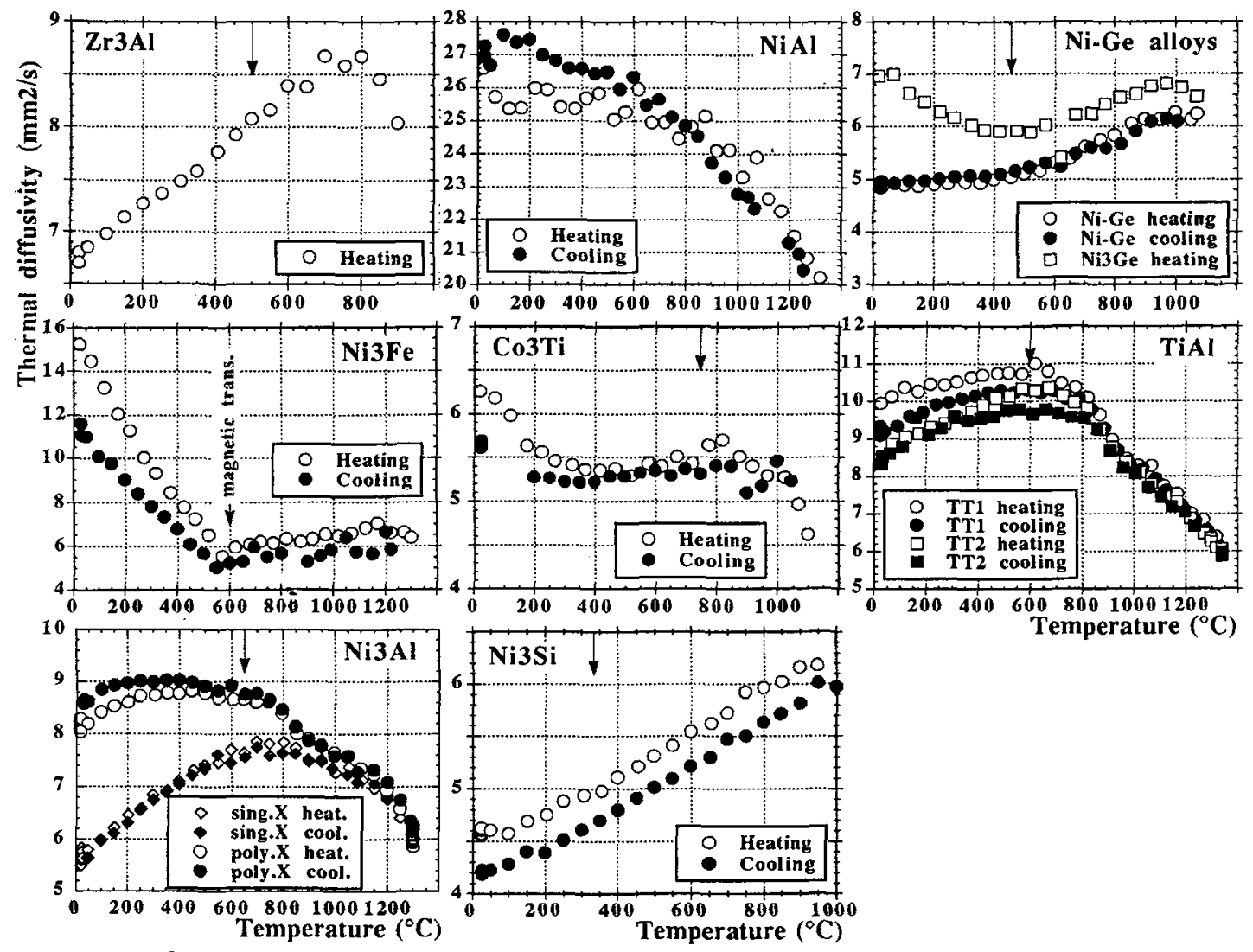

FIGURE Q: Temperature dependence of thermal diffusivity for the different intermetallic compounds of Table 1 . Stength peak temperatures are marked with an arrow. 